\title{
FLOW RATES AND SECONDARY STRUCTURES OF FOX AND FRANZ JOSEF GLACIERS, NEW ZEALAND
}

\author{
By Bernard M. Gunn \\ (Department of Geology, University of Otago, Dunedin, New Zealand)
}

\begin{abstract}
Measurements have been made of the flow rates of two adjacent glaciers in Westland, New Zealand. A longitudinal flow foliation is developed in one (Franz Josef Glacier) and this was found to be associated with more or less constant rates of flow down the length of the glacier tongue. In the other (Fox Glacier) the foliation is of the transverse type and is associated with a high strain-rate in ice under compression with markedly decreasing rates of flow being found down the length of the glacier. The highest strain-rates are associated with tectonic dirt bands and thrusts.
\end{abstract}

RÉsumé. On a fait des mesures de vitesse d'écoulement sur deux glaciers adjacents du Westland, en Nouvelle-Zélande. Une foliation dans l'écoulement longitudinal se développe sur l'un d'eux (le Franz Josef Glacier) et l'on trouve que ceci est en relation directe avec des vitesses d'écoulement plus ou moins constantes tout le long de la langue du glacier. Sur l'autre glacier (le Fox Glacier), la foliation est de type transversal, et va de pair avec une grande vitesse de déformation de la glace sous compression, alors que l'on a trouvé des vitesses d'écoulement qui diminuent sensiblement tout le long du glacier. Les vitesses de déformation les plus grandes sont associées à des bandes limoneuses et à des poussées d'origine tectonique.

Zusammenfassung. An zwei benachbarten Gletschern in Westland auf Neuseeland wurden Geschwindigkeitsmessungen ausgeführt. In einem der beiden, dem Franz Josef Glacier, ist eine Längsbänderung ausgebildet, die mit mehr oder weniger konstanten Fliessgeschwindigkeiten über die ganze Gletscherzunge hinunter verknüpft ist. Die Bänderung des zweiten, des Fox Glacier, hat transversalen Charakter, verbunden mit hohen Spannungswerten in druckbelastetem Eis und gletscherabwärts beträchtlich abnehmenden Fliessgeschwindigkeiten. Die höchsten Spannungswerte treten an tektonisch bedingten Schmutzbändern und Schubflächen auf.

\section{INTRODUCTION}

Fox and Franz Josef Glaciers are close to each other (Fig. I), are of similar size and general appearance, and incised in the western slopes of the Southern Alps. Franz Josef Glacier (Fig. 2) is about $\mathrm{I} \mathrm{I} \mathrm{km}$. long and rises in an undulating névé enclosed by mountains rising to $3,048 \mathrm{~m}$. The firn line is at about $2,000 \mathrm{~m}$. while the valley tongue is about $4 \mathrm{~km}$. long and descends a steep and broken ice fall into a deeply entrenched valley (Fig. 3a, b). In i 956 when this study was made the glacier terminated only $230 \mathrm{~m}$. above sea-level near the western escarpment of the Southern Alps but it has now retreated to an altitude of about $295 \mathrm{~m}$. (see Fig. $3 \mathrm{~b})$.

The composite névé of Fox Glacier is backed by mountains up to $3,498 \mathrm{~m}$. (Fig. 4) and the glacier has a total length of I $_{5} \mathrm{~km}$., of which the valley tongue makes up $8 \mathrm{~km}$. (Fig. 5). Below the main ice fall, however, the tongue of Fox Glacier averages only $4^{\circ}$ of slope compared with $8^{\circ}$ for Franz Josef Glacier.

Annual sedimentary layers are apparently destroyed in the course of passage down the ice falls and have not been found in the valley tongues of either glacier. This contrasts with the more gently sloping adjacent Tasman Glacier, where as many as 22 annual sedimentary layers crop out over a distance of $5 \mathrm{~km}$. below the firn line.

The ice of the lower $3 \mathrm{~km}$. of Franz Josef Glacier displays a prominent, steeply dipping longitudinal flow foliation (Fig. 6), which is a schist-like combination of parallel cleavage and alternating laminations of clear blue and white bubbly ice. In clear ice freshly exposed to the air the foliation appears to consist of parallel sheets of air bubbles, but pencil rubbings show that the ice crystals are elongated an average of 92 per cent parallel to the foliation in the horizontal plane (Fig. 7). Within a few hundred metres of the terminus this gives way to a transverse foliation which dips inwards and up-glacier at angles of $30-60^{\circ}$. In the zone of transition both foliations are present. Near the terminus there were, in i 956 , two thrust-planes 


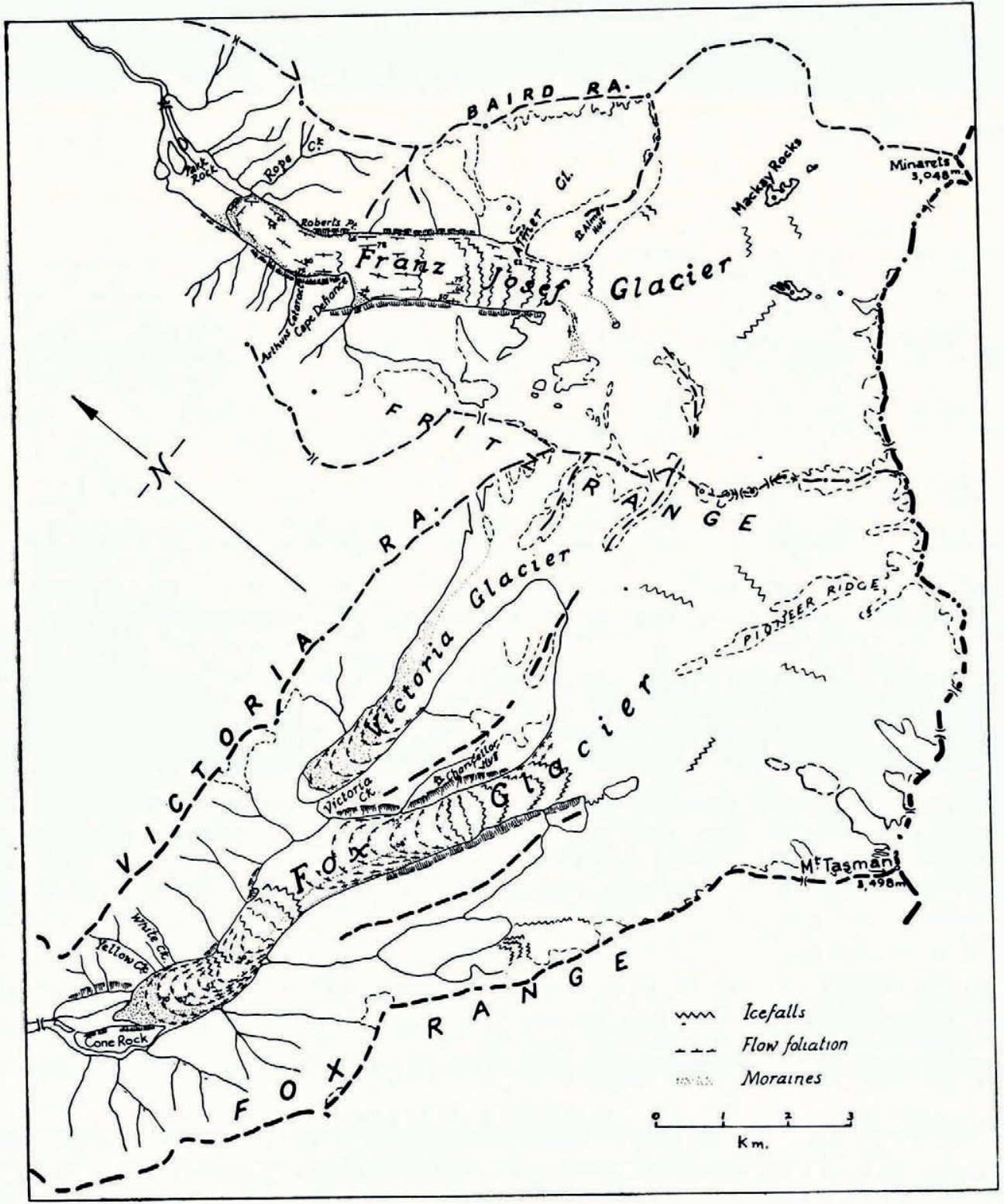

Fig. I. Locality map of the Fox and Franz Josef Glaciers, showing the strike and dip of flow foliation

or overthrust faults parallel to the foliation of the type described below as "moraine ogives" (Fig. 8).

In lower Fox Glacier flow foliation is prominent and is all of the transverse type cropping out in a broad U concave up-stream. As in Franz Josef Glacier, the ice leaves the névé by way of a steep ice fall, but at the foot of Fox Glacier ice fall are a series of crescentic ice bulges, or Forbes ogives, and the foliation is parallel to the ogives. Along the lateral margins the foliation dips inwards at angles of $70-90^{\circ}$, but along the mid-line the dip is $50-70^{\circ}$ up-glacier. Over- 


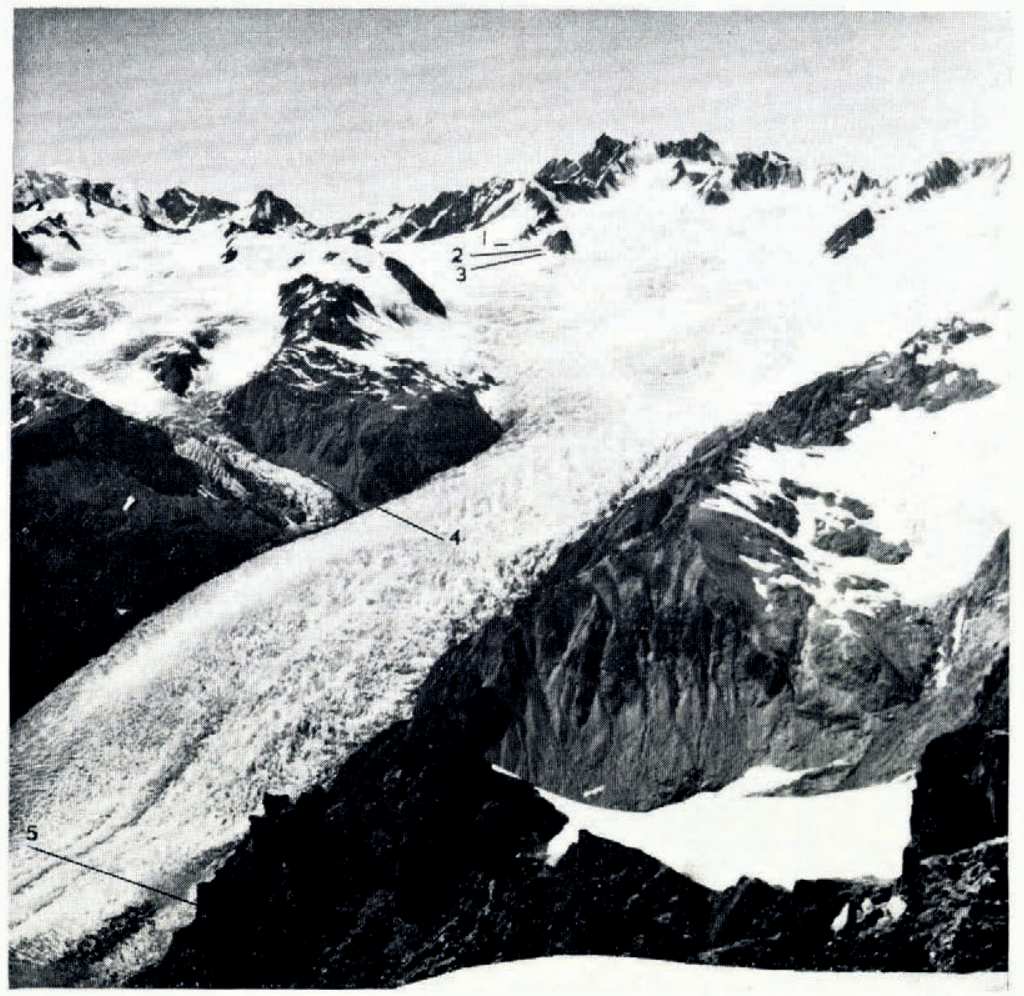

Fig. 2. The upper Franz Josef Glacier with the Minarets $\left(3,04^{8} \mathrm{~m}\right.$.) in the distance. The positions of survey lines $I$ to 5 are shown

thrusting parallel to the foliation has given rise to prominent tectonic blue bands (Fig. 9) and dirt-band ogives (for definition see [Ward], 1953) grading into prominent thrusts which include a layer of milled mud, sand and gravel, and occasional boulders up to $\mathrm{I} \mathrm{m}$. in diameter. Usually these layers do not exceed $20 \mathrm{~cm}$. in thickness but they often crop out for $200 \mathrm{~m}$. across the glacier. A combination of differential movement and ablation concentrates this rock waste into a curving arcuate supraglacial bank of moraine which may reach a height of about $5 \mathrm{~m}$. in a period of 6 months before being reduced by slumping and rain wash. Similar arcuate supraglacial moraines are to be seen near the termini of most of the major glaciers of the Southern Alps.

The hanging wall of the faults projects in places as much as $2 \mathrm{~m}$. over the lower wall but the overhang may be due to more rapid ablation of the dirty lower surface (Fig. Io).

The term for thrust faults with included moraine suggested by [Ward] (r953) of "debris laden shear-plane ogives" is too cumbersome for ordinary use and the writer would prefer the term "moraine ogives".

\section{Glacier Equilibrium}

In company with the majority of glaciers of the temperate regions, Fox and Franz Josef Glaciers have been retreating at an accelerating rate since the first records were made in 1867 , especially since 1935. Fluctuations of Franz Josef Glacier have been summarized up to $194^{8}$ by Suggate (1950). Franz Josef Glacier retreated approximately $660 \mathrm{~m}$. between r 935 and 


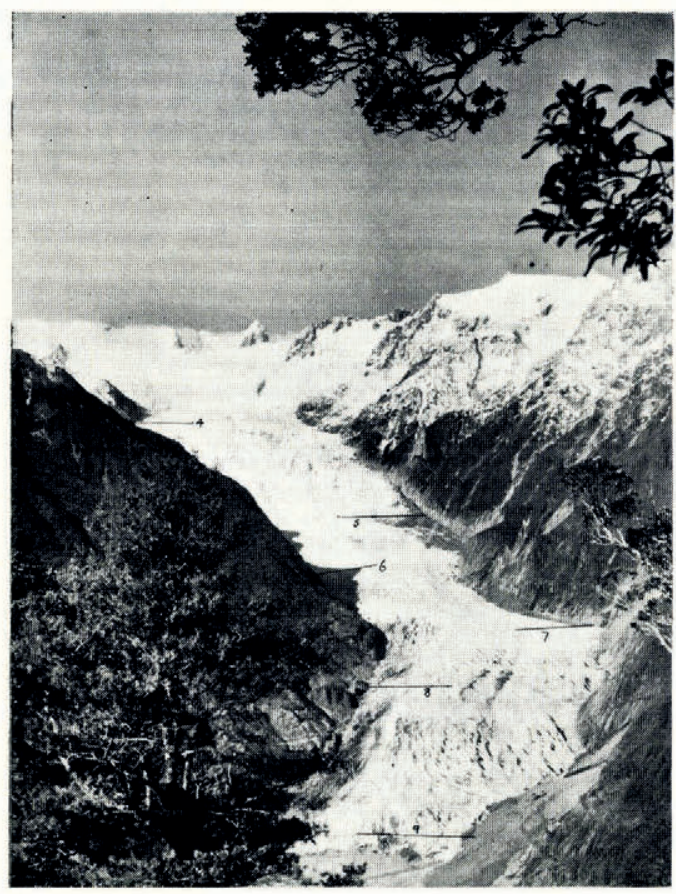

a.

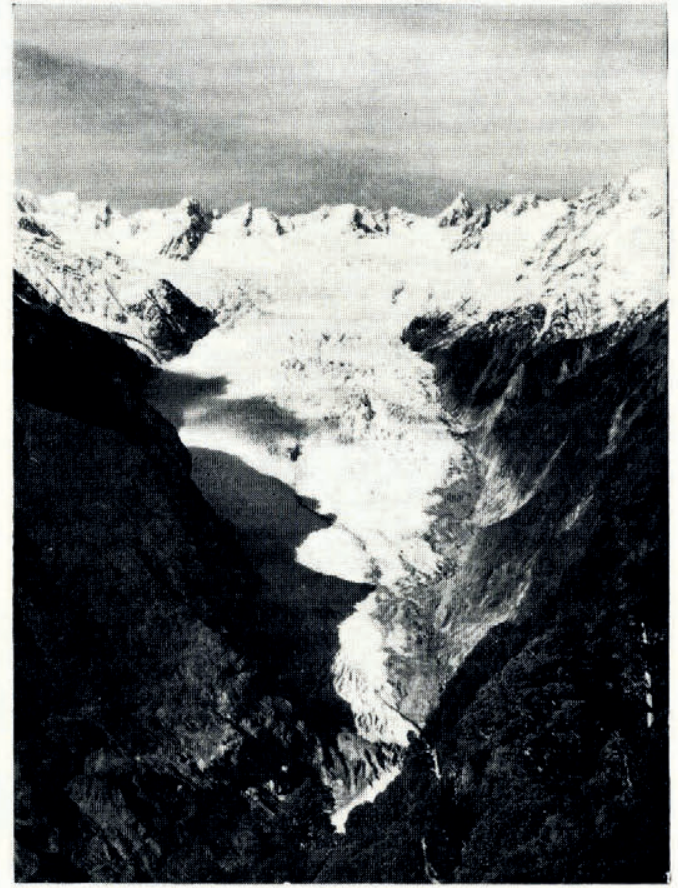

$b$.

Fig. 3. Franz Josef Glacier. (a) Survey lines 4 to 9 are shown; (b) In the winter of 1961 showing recession since 1956. (National Publicity Studios photographs)

1956 and thinned about $100 \mathrm{~m}$. over the lower reaches. Following a winter of unusually heavy snowfall in 1946 the glacier thickened greatly and in 1948 it advanced about $0.5 \mathrm{~km}$. but by $195^{I}$ it had resumed the general retreat. Since $195^{6}$ further retreat of about $600 \mathrm{~m}$. has taken place (personal communication from W. Sara).

Fox Glacier retreated I,00o m. between 1935 and 1956 and a further $800 \mathrm{~m}$. since then.

\section{Rates of Flow of Franz Josef Glacier}

In March 1956, measurements of flow rates were made along nine transverse profiles at a total of 33 stations (Fig. I I). Three of the profiles were in the névé region and six in the valley. The latter profiles each extended about half the width of the glacier from fixed bases situated on alternate sides of the glacier. Measurements were made by theodolite over periods of 6 to $4^{8} \mathrm{hr}$., a longer period being used where flow was slowest. Error is considered to be less than 5 per cent at all stations other than line 4 on Franz Josef Glacier where, due to ice instability, observation only lasted $6 \mathrm{hr}$. and error may be as high as \pm Io per cent. In all other cases the duration of observation exceeded $24 \mathrm{hr}$. Repeated measurements did not indicate more than minor diurnal fluctuations. Typical of many workers is the experience of Meier and others (1954) who found diurnal variations of up to $5^{\circ}$ per cent on Saskatchewan Glacier, but the high temperatures with low daily range experienced at low altitude in Westland, New Zealand, could be expected to minimize such effects.

Only the horizontal component of movement was measured, although it has been shown theoretically by Reid ( 1896 ) and found in practice by Perutz and Seligman (1939) that there 


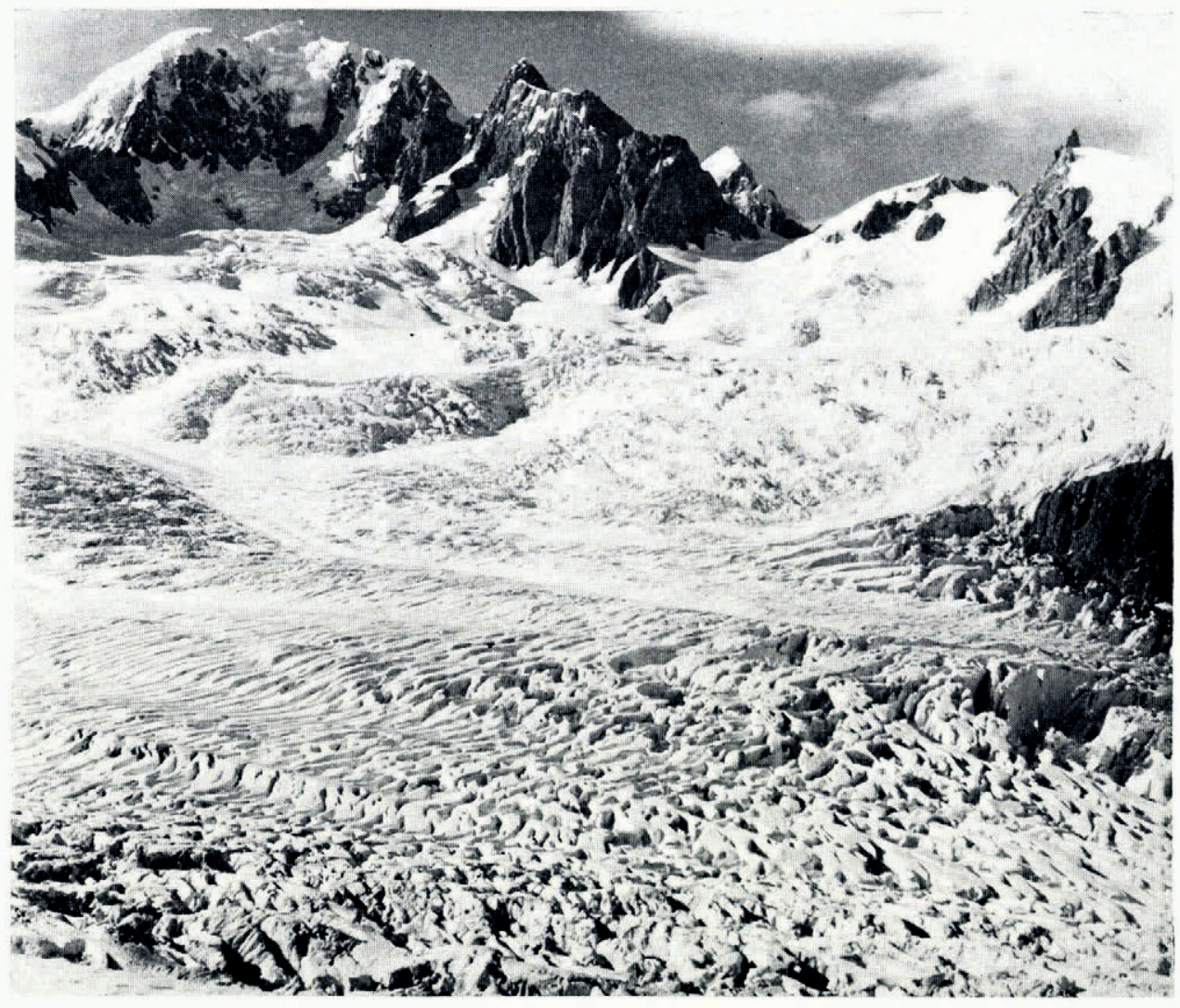

Fig. 4. Part of the névé of Fox Glacier with (from the left) Mounts Tasman and Torres with Mount Cook $(3,764 m$.) in the distance. Note the $U$-shaped slump beginning to form on the right near the top of the Fox Glacier ice fall

is, in addition, an upward and outward component in the region of ablation and an inward and downward component in the region of accumulation.

In Table I the distance of the stations up-glacier is referred to Park Rock, a prominent roche moutonnée which was then $657 \mathrm{~m}$. from the glacier terminus.

Maximum flow rates in general were found near the mid-line of the glacier (Table I) with the highest rate $(245 \mathrm{~cm}$./day) immediately below the point where the névé enters the constricted valley and above a steep ice fall of $30^{\circ}$ slope. The great reduction in flow rate at the foot of this ice fall to $66 \mathrm{~cm}$./day must indicate considerable thickening of the glacier at this point.

As the glacier is now in a state of retreat, the flow rates are low compared with those measured during periods of ice advance in the past. Thus, Bell (1910) recorded a rate of $6 \mathrm{r} \mathrm{cm}$./day in 1908 near the present terminus when the ice was about $60 \mathrm{~m}$. thicker and reached about $700 \mathrm{~m}$. farther down-valley, while a rate of $90 \mathrm{~cm}$./day was recorded near the terminus at the height of the 1948 advance (personal communication from R. Warburton).

\section{Rates of Flow of Fox Glacier}

In January I955 stakes were placed at intervals up Fox Glacier as near as possible to the 
mid-line (Fig. 12), and the flow rates were recorded at intervals over periods ranging from 5 to 6 I days (Table II). Again, there appeared to be no short-term variations.

In April r956 a further set of measurements was made on Fox Glacier (Table III). The datum referred to is the position of the terminus in 1955 when it was opposite a tourist gallery on Cone Rock, a prominent roche moutonnée, but in the interim period of 14 months the ice front had retreated $300 \mathrm{~m}$. and the surface of the lower glacier had dropped by about $15 \mathrm{~m}$.

Table I. Flow Rates of Franz Josef Glacier, 1956

\begin{tabular}{|c|c|c|c|c|c|}
\hline Line & $P e g$ & $\begin{array}{l}\text { Distance from } \\
\text { Park Rock }\end{array}$ & $\begin{array}{l}\text { Distance from } \\
\text { bank }\end{array}$ & Flow rate & Locality \\
\hline & & $\mathrm{km}$. & m. & $\mathrm{cm} . /$ day & \\
\hline I & $\mathrm{a}$ & $10 \cdot 0$ & 200 & $3 \cdot 8$ & Mackay Rocks \\
\hline 2 & $\begin{array}{l}a \\
b \\
c \\
d\end{array}$ & $\begin{array}{l}9 \cdot 5 \\
9 \cdot 5 \\
9 \cdot 5 \\
9 \cdot 5\end{array}$ & $\begin{array}{r}9^{\circ} \\
27^{\circ} \\
365 \\
55^{\circ}\end{array}$ & $\begin{array}{r}3 \cdot 1 \\
6 \cdot 4 \\
11 \cdot 7 \\
18 \cdot 5\end{array}$ & Mackay Rocks \\
\hline 3 & $\begin{array}{l}a \\
b \\
c \\
d\end{array}$ & $\begin{array}{l}9 \cdot 0 \\
9 \cdot 0 \\
9 \cdot 0 \\
9 \cdot 0\end{array}$ & $\begin{array}{l}117 \\
270 \\
455 \\
640\end{array}$ & $\begin{array}{r}7 \cdot 4 \\
8 \cdot 1 \\
20 \cdot 3 \\
19 \cdot 5\end{array}$ & Mackay Rocks \\
\hline 4 & $\begin{array}{l}a \\
b \\
c \\
d\end{array}$ & $\begin{array}{l}5 \cdot 5 \\
5 \cdot 5 \\
5 \cdot 5 \\
5 \cdot 5\end{array}$ & $\begin{array}{r}2 \\
67 \\
213 \\
412\end{array}$ & $\begin{array}{r}50 \cdot 8 \\
132 \cdot 1 \\
132 \cdot 1 \\
245 \cdot 1\end{array}$ & Almer Junction \\
\hline 5 & $\begin{array}{l}a \\
b \\
c \\
d \\
e\end{array}$ & $\begin{array}{l}4 \cdot 4 \\
4 \cdot 4 \\
4 \cdot 4 \\
4 \cdot 4 \\
4 \cdot 4\end{array}$ & $\begin{array}{r}3 \\
87 \\
170 \\
220 \\
365\end{array}$ & $\begin{array}{r}8 \cdot 3 \\
31 \cdot 7 \\
54 \cdot 0 \\
66 \cdot 0 \\
63 \cdot 5\end{array}$ & Foot of ice fall \\
\hline 6 & $\begin{array}{l}\mathrm{a} \\
\mathrm{b} \\
\mathrm{c} \\
\mathrm{d}\end{array}$ & $\begin{array}{l}2 \cdot 9 \\
2 \cdot 9 \\
2 \cdot 9 \\
2 \cdot 9\end{array}$ & $\begin{array}{r}\text { I } \\
63 \\
146 \\
231\end{array}$ & $\begin{array}{l}40 \cdot 6 \\
54 \cdot 6 \\
59 \cdot 4 \\
54 \cdot 6\end{array}$ & Cape Defiance \\
\hline 7 & $\begin{array}{l}a \\
b \\
c \\
d\end{array}$ & $\begin{array}{l}2 \cdot 3 \\
2 \cdot 3 \\
2 \cdot 3 \\
2 \cdot 3\end{array}$ & $\begin{array}{r}57 \\
114 \\
236 \\
455\end{array}$ & $\begin{array}{r}5 \cdot 1 \\
15 \cdot 9 \\
33 \cdot 0 \\
36 \cdot 6\end{array}$ & Arthurs Cataract \\
\hline 8 & $\begin{array}{l}a \\
b \\
c \\
d\end{array}$ & $\begin{array}{l}\mathrm{I} \cdot 6 \\
\mathrm{I} \cdot 6 \\
\mathrm{I} \cdot 6 \\
\mathrm{I} \cdot 6\end{array}$ & $\begin{array}{r}3 \\
55 \\
137 \\
164\end{array}$ & $\begin{array}{r}6 \cdot 9 \\
27 \cdot 2 \\
37 \cdot 3 \\
36 \cdot 1\end{array}$ & Roberts Point track \\
\hline 9 & $\begin{array}{l}\mathrm{a} \\
\mathrm{b}\end{array}$ & $\begin{array}{l}0.5^{8} \\
0.5^{8}\end{array}$ & - & $\begin{array}{l}8 \cdot 9 \\
5 \cdot 7\end{array}$ & Terminal face \\
\hline Io & a & 0.4 & - & o & $\begin{array}{l}\text { Moraine-covered ice } \\
\text { hummock }\end{array}$ \\
\hline
\end{tabular}

Table II. Flow Rates of Fox Glacier, January-February 1955

\begin{tabular}{ccrl} 
Peg & $\begin{array}{c}\text { Distance from } \\
\text { terminus }\end{array}$ & Flow rate & \multicolumn{1}{c}{ Locality } \\
& $\mathrm{m}$. & $\mathrm{cm} \cdot / \mathrm{day}$ & \\
$\mathrm{A}$ & & $\mathrm{1} 3 \mathrm{I} \cdot 3$ & Victoria Creek \\
$\mathrm{B}$ & 4,570 & $4 \mathrm{I} \cdot 9$ & Below lower ice fall \\
$\mathrm{C}$ & $\mathrm{1}, 938$ & $32 \cdot 0$ & Yellow Creek \\
$\mathrm{D}$ & 914 & $\mathrm{I} 2 \cdot 7$ & On terminal moraines \\
$\mathrm{E}$ & 686 & $7 \cdot 7$ & On terminal moraines \\
$\mathrm{F}$ & 457 & $5 \cdot \mathrm{I}$ & On terminal moraines
\end{tabular}


FLOW RATES OF FOX AND FRANZ JOSEF GLACIERS

Table III. Flow Rates of Fox Glacier, April 1956

\begin{tabular}{ccccl} 
Peg & $\begin{array}{c}\text { Distance from } \\
\text { I.955 termizus }\end{array}$ & $\begin{array}{c}\text { Distance from } \\
\text { margin }\end{array}$ & Flow rate & \multicolumn{1}{c}{ Locality } \\
$\mathrm{A}_{1}$ & $\mathrm{~m}$. & $\mathrm{m}$. & $\mathrm{cm} . /$ day & \\
$\mathrm{C}_{1}$ & 4,480 & 224 & $38 \cdot \mathrm{I}$ & Victoria Creek \\
$\mathrm{C}_{2}$ & $\mathrm{I}, 000$ & 64 & $7 \cdot 9$ & Yellow Creek \\
$\mathrm{C}_{3}$ & $\mathrm{I}, 000$ & 133 & $14 \cdot 6$ & Yellow Creek \\
$\mathrm{D}_{1}$ & $\mathrm{I}, 000$ & 230 & $2 \mathrm{I} \cdot 6$ & Yellow Creek \\
& 690 & 150 & $4 \cdot \mathrm{I}$ & On terminal moraines
\end{tabular}

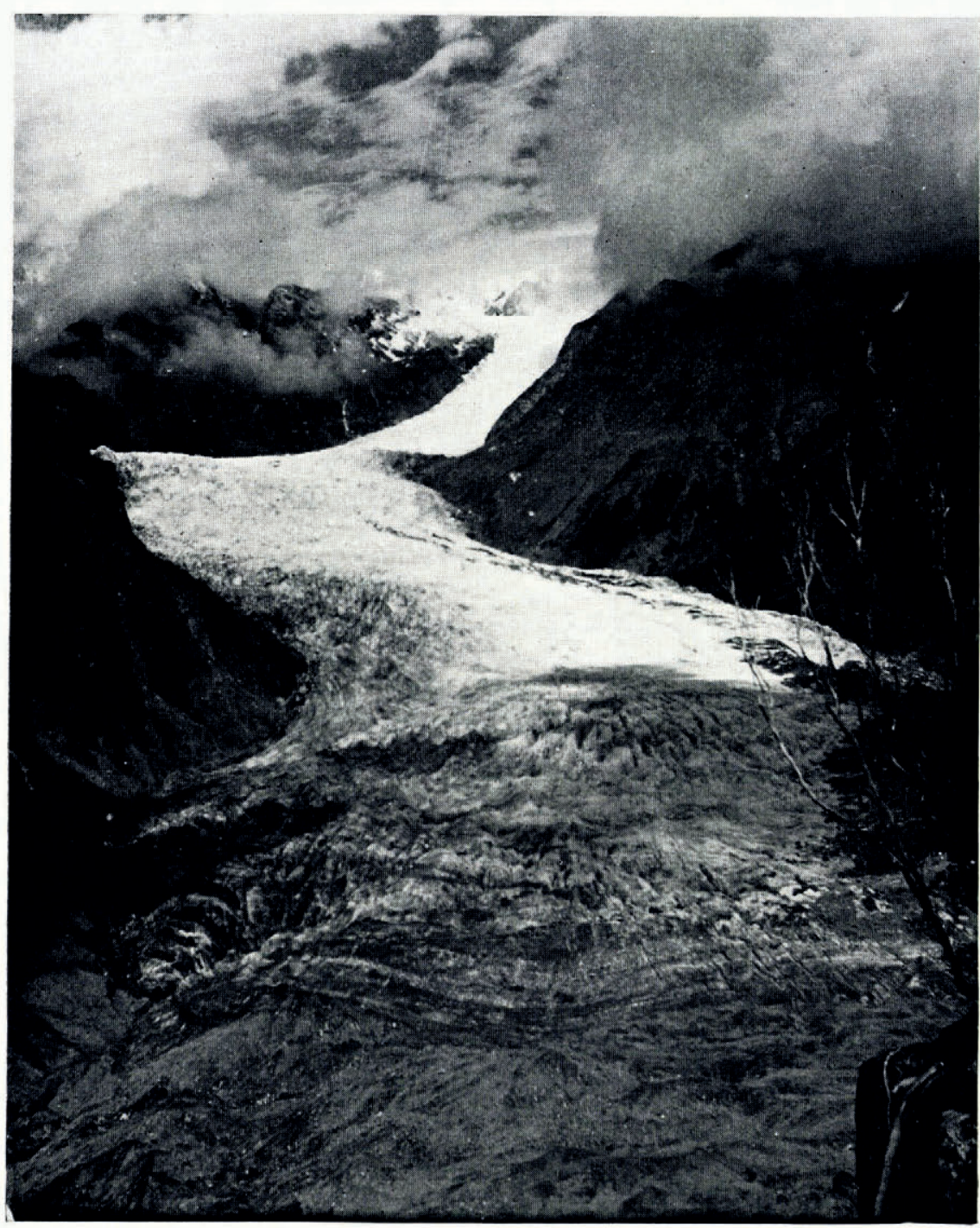

Fig. 5. Fox Glacier from Cone Rock. Note the transverse foliation, crevasses and thrusting on the left 


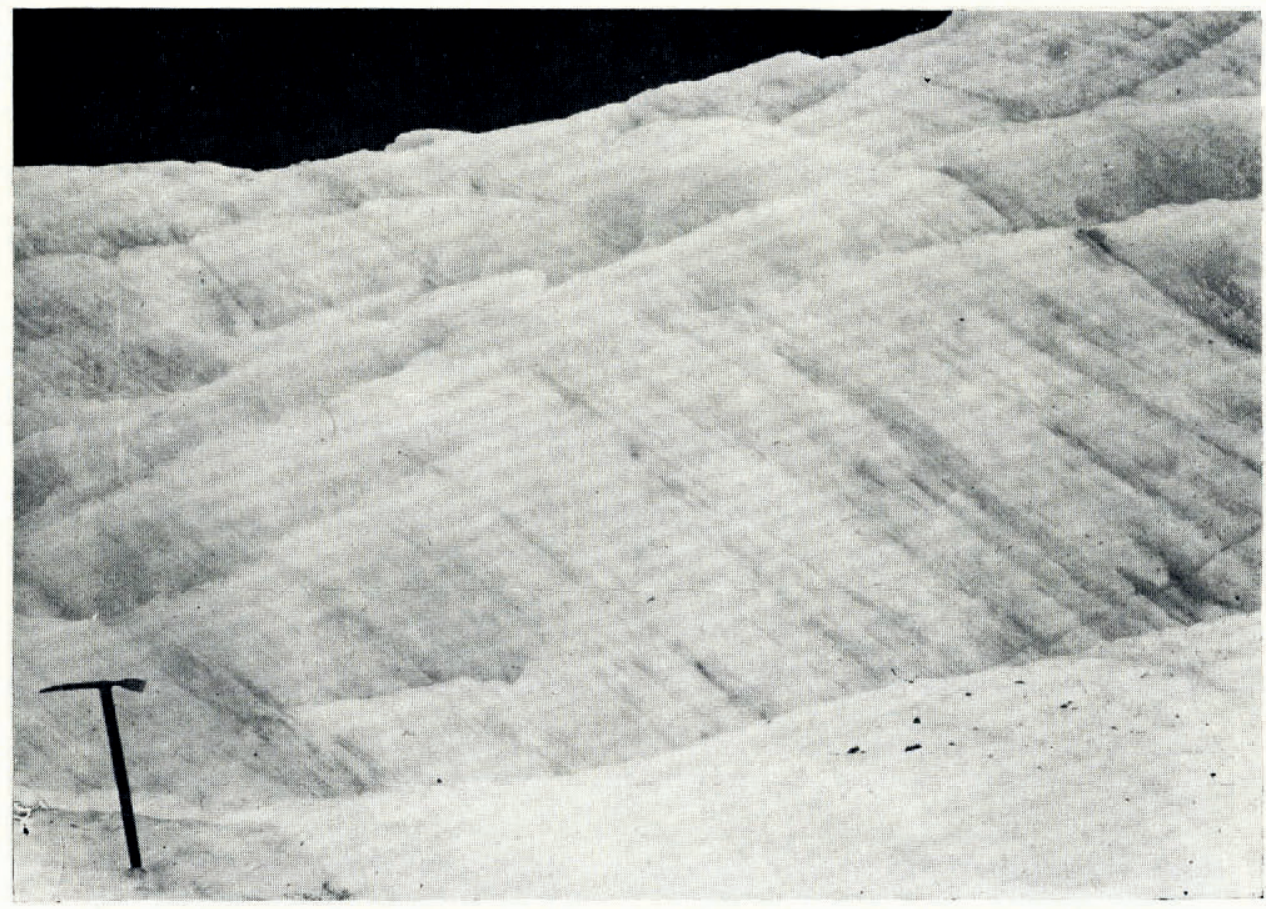

Fig. 6. Longitudinal foliation in Franz Fosef Glacier about $\mathrm{I} \mathrm{km}$. from the terminus

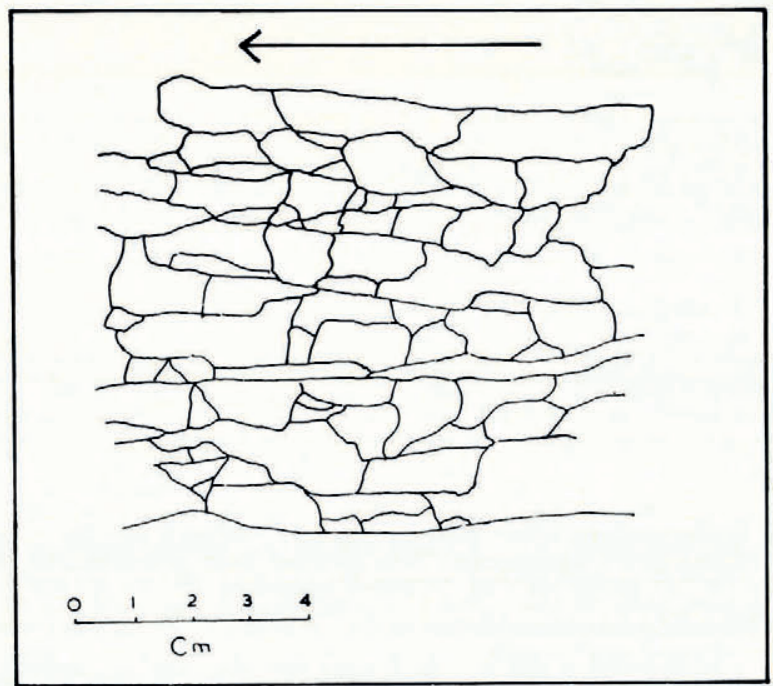

Fig. 7. Copy of pencil rubbings of a horizontal section of ice crystals in the longitudinal foliated ice, Franz Fosef Glacier. The direction of flow is shown 
These stakes were placed as near as possible to the stakes of the same number of the previous year, with $\mathrm{C}_{2}$ in the line $\mathrm{C}_{1}, \mathrm{C}_{2}, \mathrm{C}_{3}$ approximately coinciding with $\mathrm{C}$ of the year before. $\mathrm{A}$ marked decrease in flow rate averaging about 35 per cent is shown, which, in view of the rapid retreat of the glacier, is not unexpected.

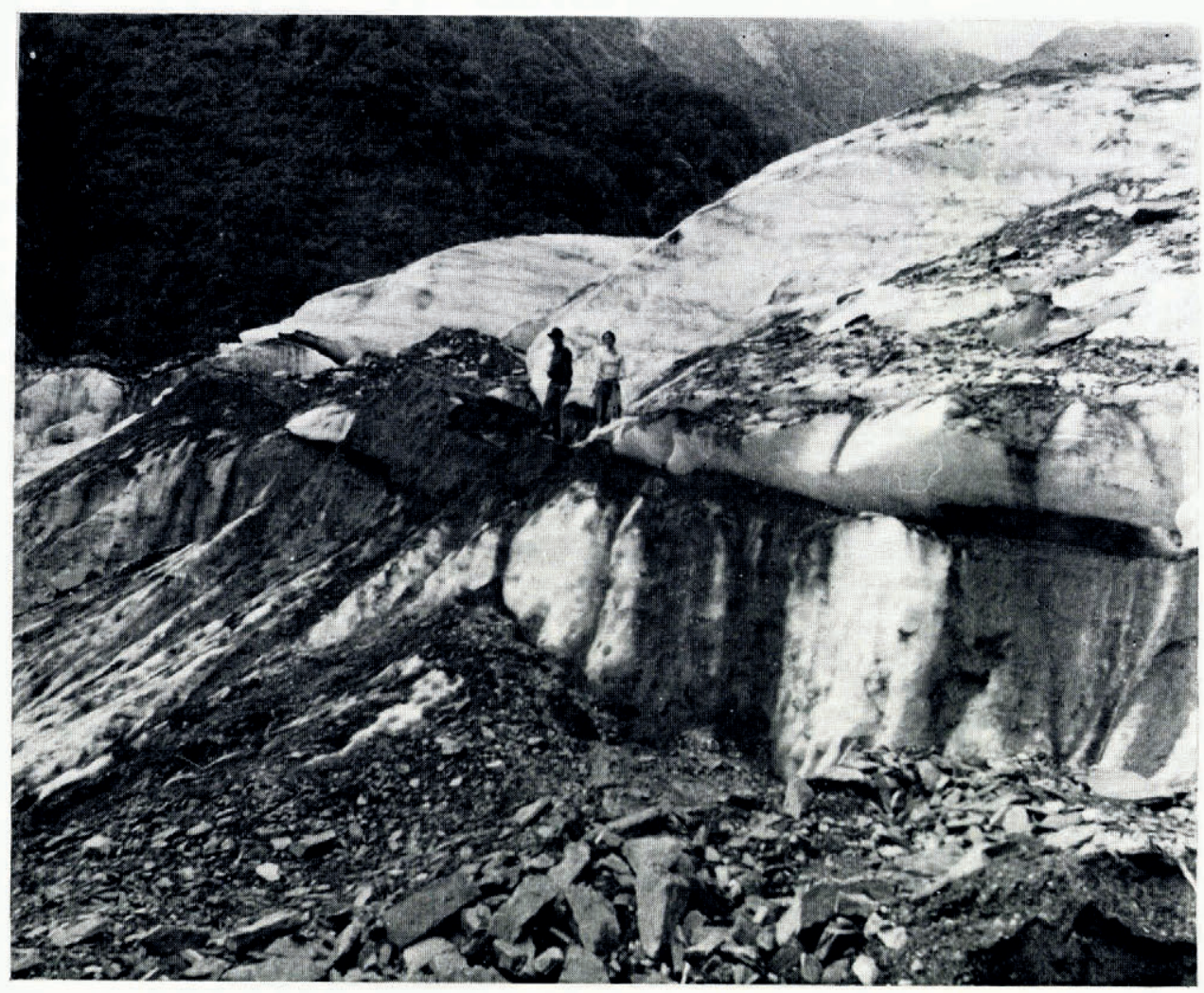

Fig. 8. Compressive foliation and a moraine ogive at the terminus of Franz Josef Glacier, 1955

Marginal and Basal Slip

At lines 4, 5, 6 and 8 on Franz Josef Glacier (Fig. I3) it was possible to place movement stakes on the very edge of the glacier. The amount of marginal slip relative to the maximum flow rate near the centre of the glacier can be expressed as:

$$
M_{s}=\frac{V_{m}}{V_{s}} \times \mathrm{IOO}
$$

where $V_{m}=$ maximum flow rate near the middle of the glacier, and $V_{s}=$ marginal flow rate at the side of the glacier.

The marginal slip at line 4 was $20 \cdot 7$ per cent, $68 \cdot 3$ per cent at line 6 and $18 \cdot 4$ per cent at line 8 . At lines 5 and 7 the marginal slip was lower, being less than 12 per cent. The marginal slip was greatest where the enclosing valley walls are steepest.

No estimates can be made of the amount of basal slip, though the presence of dirt bands 
and moraine ogives containing garnet-schist, a rock type extending only $5 \mathrm{~km}$. up-glacier, show that some slip is taking place near the termini of both glaciers.

There is little information on the amounts of basal slip in other glaciers but McCall (1952) found a basal slip of 90 per cent in a cirque glacier only $5^{\circ} \mathrm{m}$. thick, while Gerrard and others (1952) found it to be $5^{\circ}$ per cent in a glacier $130 \mathrm{~m}$. thick.

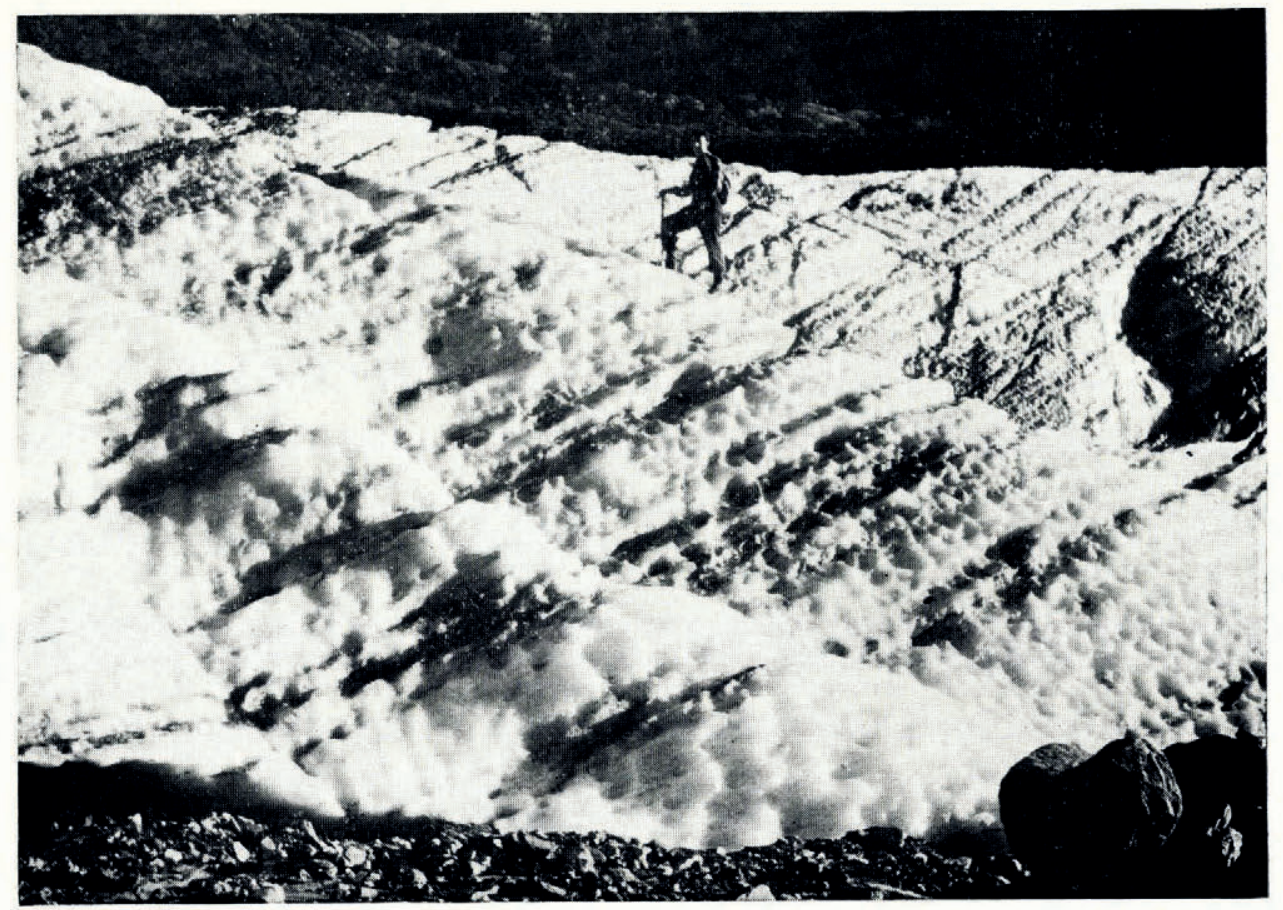

Fig. 9. Compressize foliation on Fox Glacier, with dirt-band ogives etched by accelerated ablation. Note the crevasses crossing the foliation at right-angles

\section{Strain Rates and Correlation with Structures}

The flow rate of the ice in the lower part of Fox Glacier decreases rapidly towards the terminus (Fig. I4). This is to be expected as it has long been known that the ablation zone of a glacier must be in a state of compression. Thickening consequent on this compression compensates in part for the losses by ablation (Reid, 1896 ).

Places at which the flow rate decreases most rapidly coincide with areas of well-developed transverse foliation, dirt bands and moraine ogives. This state of affairs is also supported by classical theory, as Nye (1952) has deduced the possible slip planes of a glacier under compression and one set of these closely approximates in attitude to that of the thrust faults, dirt bands and foliation found. The characteristic U-shape concave up-glacier in plan of these features is, of course, due to marginal drag.

By comparing the difference in flow rate between two adjacent points along the median line of the glacier, a strain-rate can be derived and this can then be compared with the type of deformation structure found. The expression used is

$$
\text { Percentage strain }\left(\text { day }^{-1}\right)=\frac{V_{1}-V_{2}}{S} \times 100,
$$




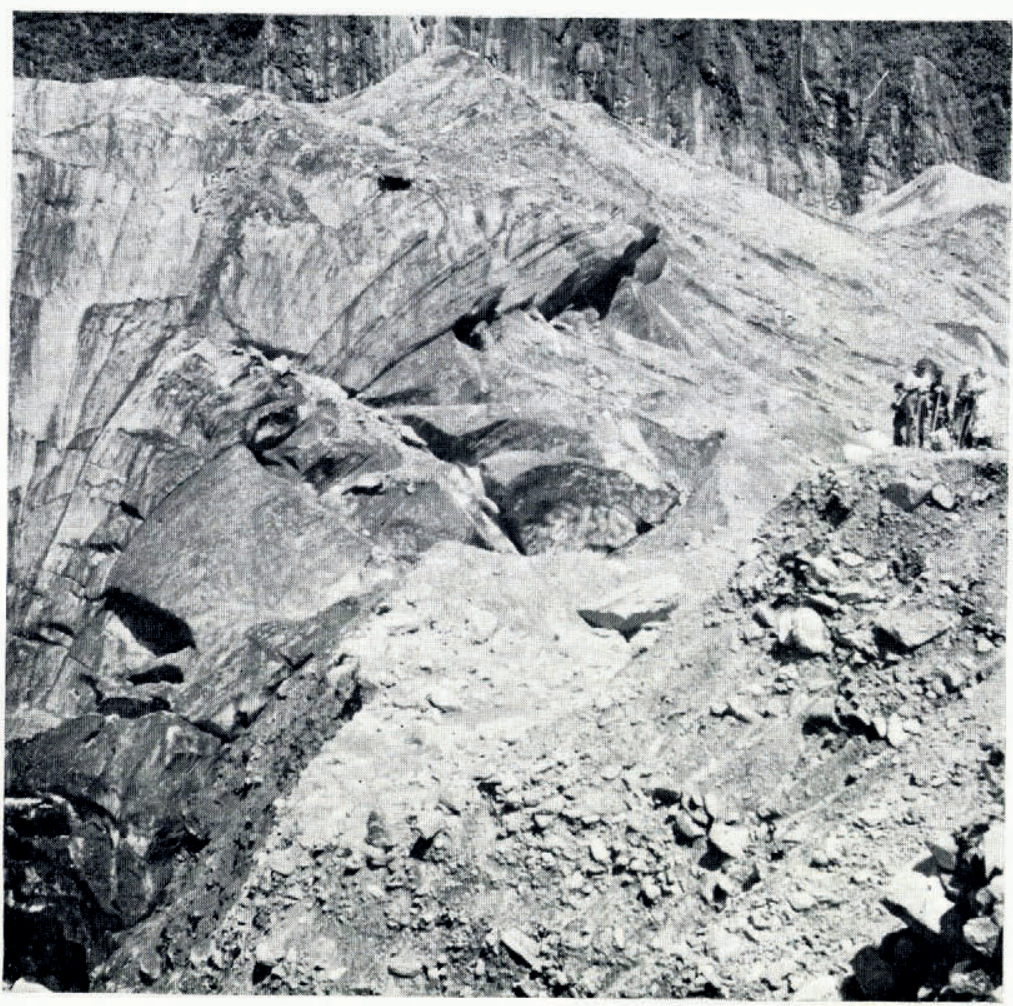

Fig. Io. Overthrusting along a moraine ogive, which is building up a moraine in the background; Fox Glacier, 1956

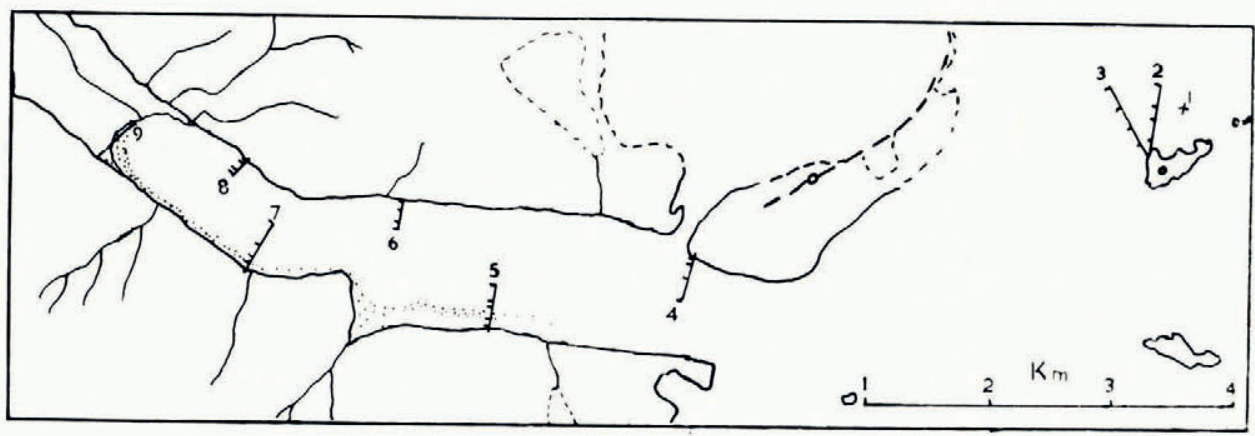

Fig. 11. Map of part of Franz Josef Glacier showing the location of survey stations 


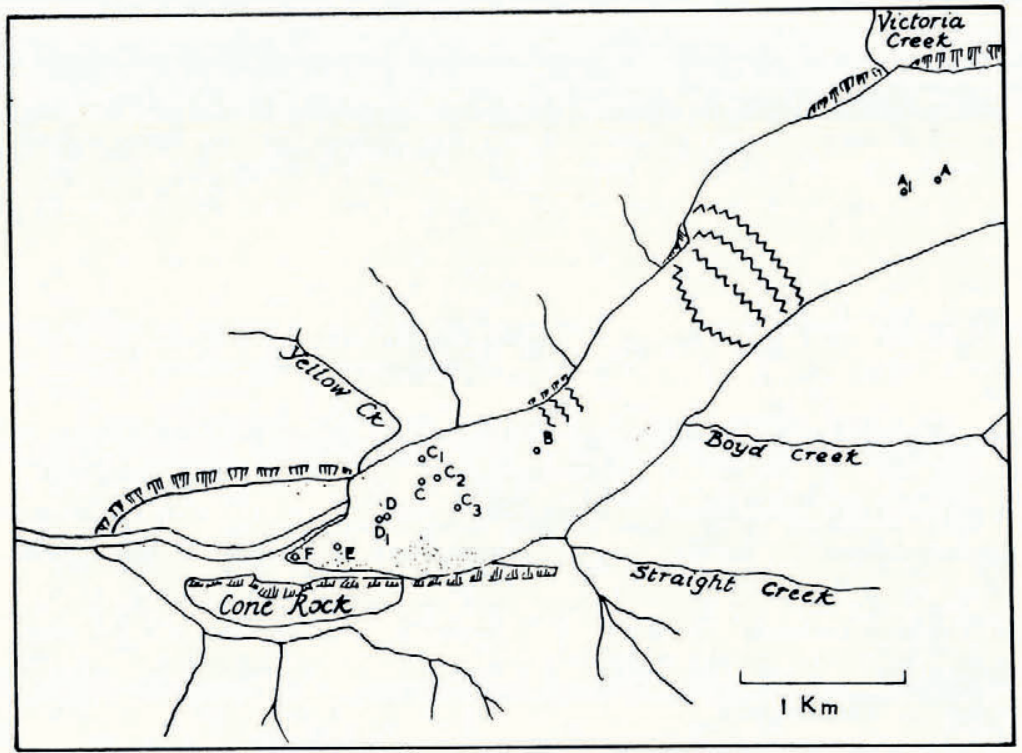

Fig. 12. Map of part of Fox Glacier showing the location of survey stations

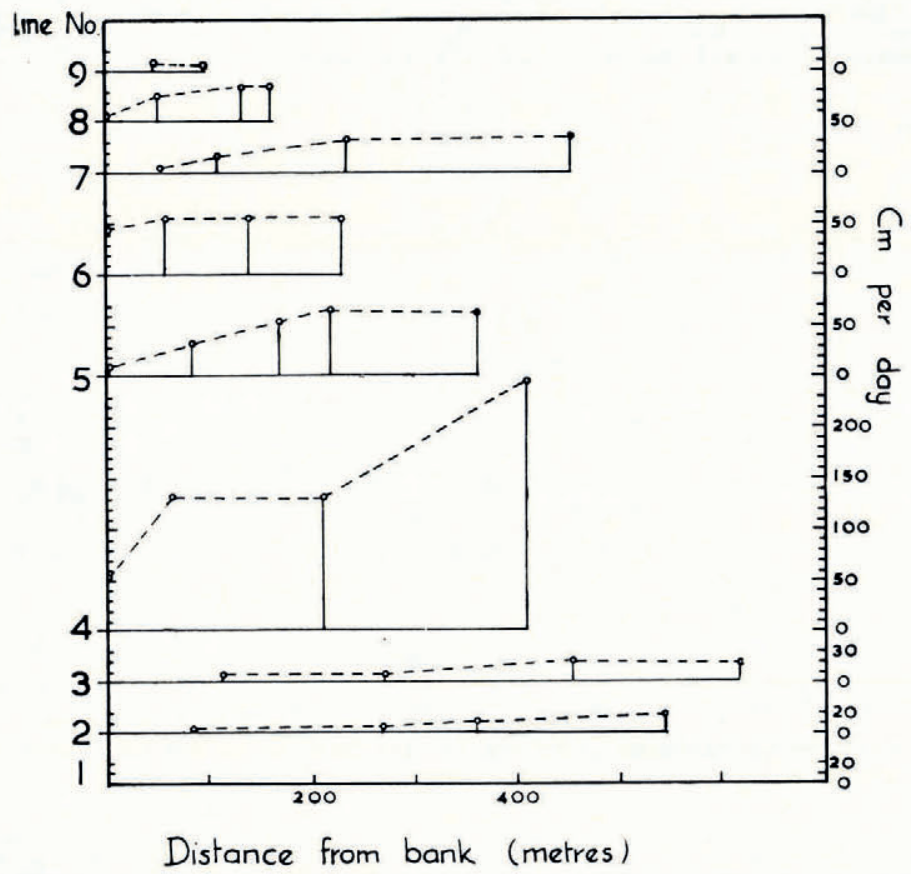

Fig. 13. Flow-rate profiles for Franz Josef Glacier 

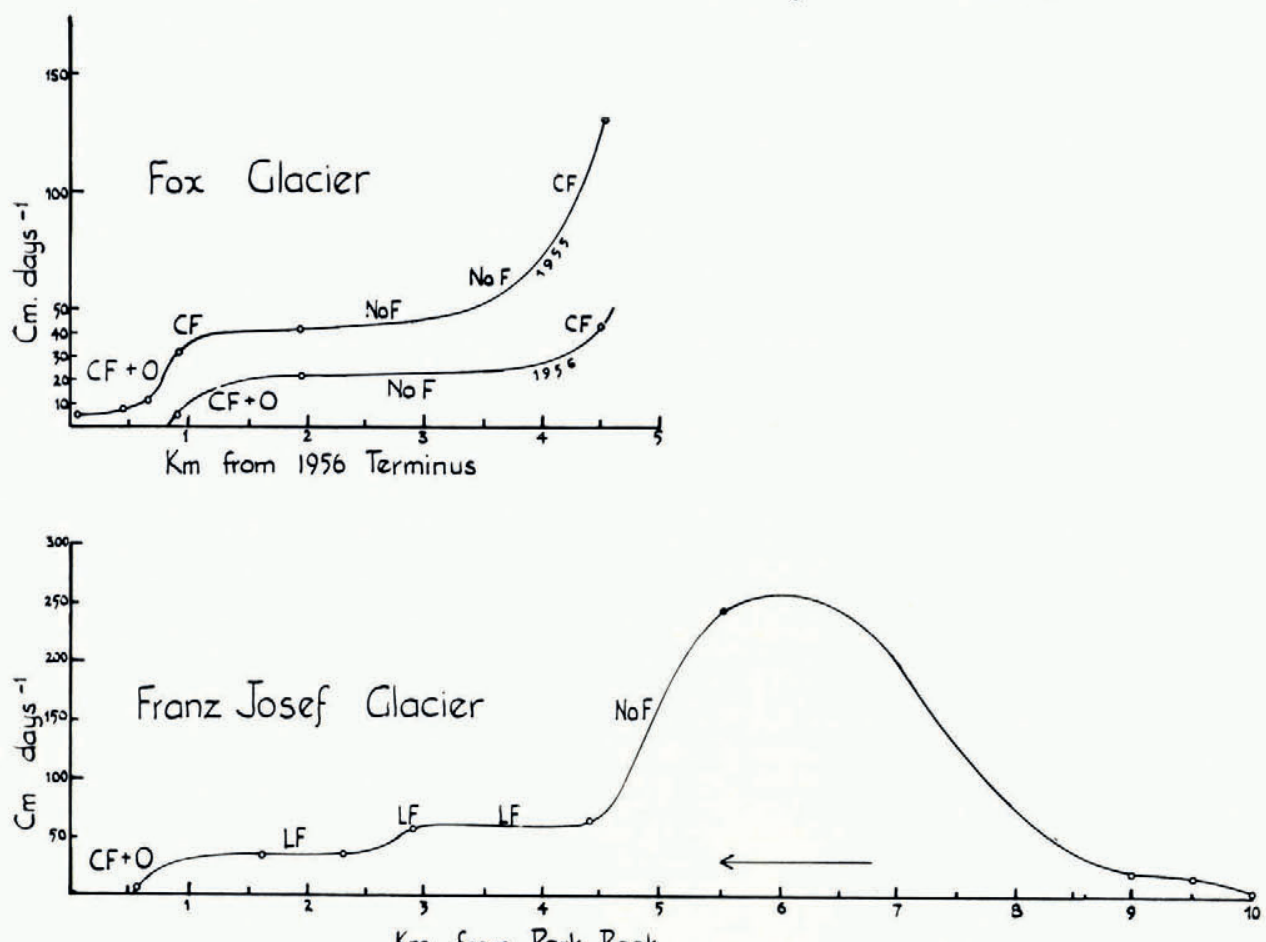

$\mathrm{Km}$. from Park Rock

Fig. 14. Variation in flow rate along the length of Franz Josef (1956) and Fox Glaciers (1955 and 1956). CF = compressive foliation; $L F=$ longitudinal foliation; $\mathrm{NoF}=$ no foliation; $O=$ moraine ogives

where $V_{1}=$ daily displacement of a point on the median line; $V_{2}=$ daily displacement of a point also on the median line a short distance down-glacier of $V_{\mathrm{r}} ; S=$ horizontal distance between points.

It is not considered likely that the strain-rate stays constant over long periods of time. Ideally, the two points taken should lie as close together as possible but this was not found to be practical, because it would take a long period of time to establish accurately the differential flow rate with the methods used. When this was attempted, the stakes melted out. However, with points 200 to $\mathrm{r}, 000 \mathrm{~m}$. apart additional factors affecting the horizontal component of flow rate must play a part, such as differences in slope and thickness of the ice between the two points and loss of intervening ice by ablation, while thrust formation may have been triggered in some places by bottom irregularities. Nevertheless, there is a fair correspondence between compression rate and structure in the different glaciers and at different times. These may be summarized as follows:

Daily strain-rate

o. o I per cent compression to

o. OOI per cent extension

o. OI to $0 \cdot 04$ per cent compression

$0 \cdot 04$ to $0 \cdot 05$ per cent compression

$0 \cdot 05$ to $0 . \mathrm{I}$ per cent compression

\section{Structure found}

Longitudinal foliation.

Transverse tectonic blue bands dipping upglacier at about $40^{\circ}$, grading into weak transverse foliation.

Well-developed transverse foliation with closely spaced dirt-band ogives.

As above together with moraine ogives up to $20 \mathrm{~cm}$. thick at intervals of 10 to $50 \mathrm{~m}$. 
Relict structures may persist for some time in a region where the strain-rate is lower than that existing at the time of formation. Overfolds of compressive foliation (Fig. 15) persisted for some months though deformation was so severe that it was unlikely that slip could still be taking place parallel to the foliation. The presence of such folds also demonstrates that plastic deformation can occur in addition to the deformation taking place along discrete slip planes. Ice moving from the zone of longitudinal foliation to the zone of compressive flow near the terminus of Franz Josef Glacier has obliterated the old foliation and developed the new one in the course of a year, though in an intermediate zone both sets of folii are present. Unstressed ice exposed in seracs recrystallizes rapidly with increase in grain-size from the range 1 to $2 \mathrm{~cm}$. to the range 5 to $10 \mathrm{~cm}$. with loss of foliation, in the course of very few weeks.

The non-appearance of a compressive transverse foliation at the foot of Franz Josef Glacier ice fall where the daily compression rate is as high as $0 .{ }_{1} 6$ per cent is not accounted for. Possibly such a foliation is formed at depth but, as the glacier then enters a region of extending or laminar flow, the foliation is immediately replaced by the longitudinal type before it becomes visible at the surface. Possibly the fact that the flow in the ice fall is Block-Schollen may also be significant.

Of great interest are a series of glacier slumps or normal faults forming great U-shaped crevasses concave down-glacier, which originate at the head of the main Fox Glacier ice fall where the ice must be under great longitudinal tension (Fig. I6). These are similar in shape to the slip planes deduced by Nye (1952) for a glacier under extending flow, but they occur at intervals of about $100-150 \mathrm{~m}$. and are crossed by the usual convex up-glacier crevasses typical

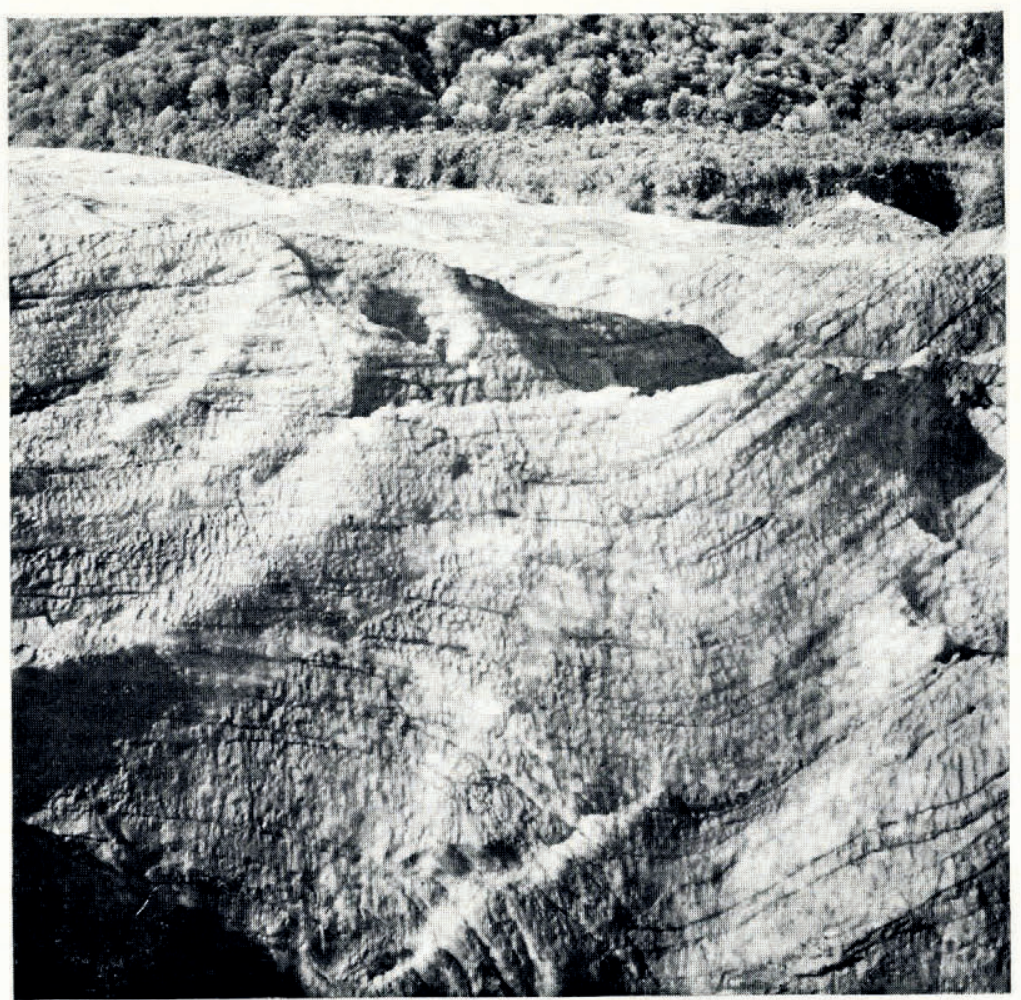

Fig. 15. Overfolding of compressive foliation at depth in the lower Fox Glacier, 1956. Note the small moraine arc in the right background. The tree trimline in the distance probably dates from the early nineteenth or late eighteenth century 


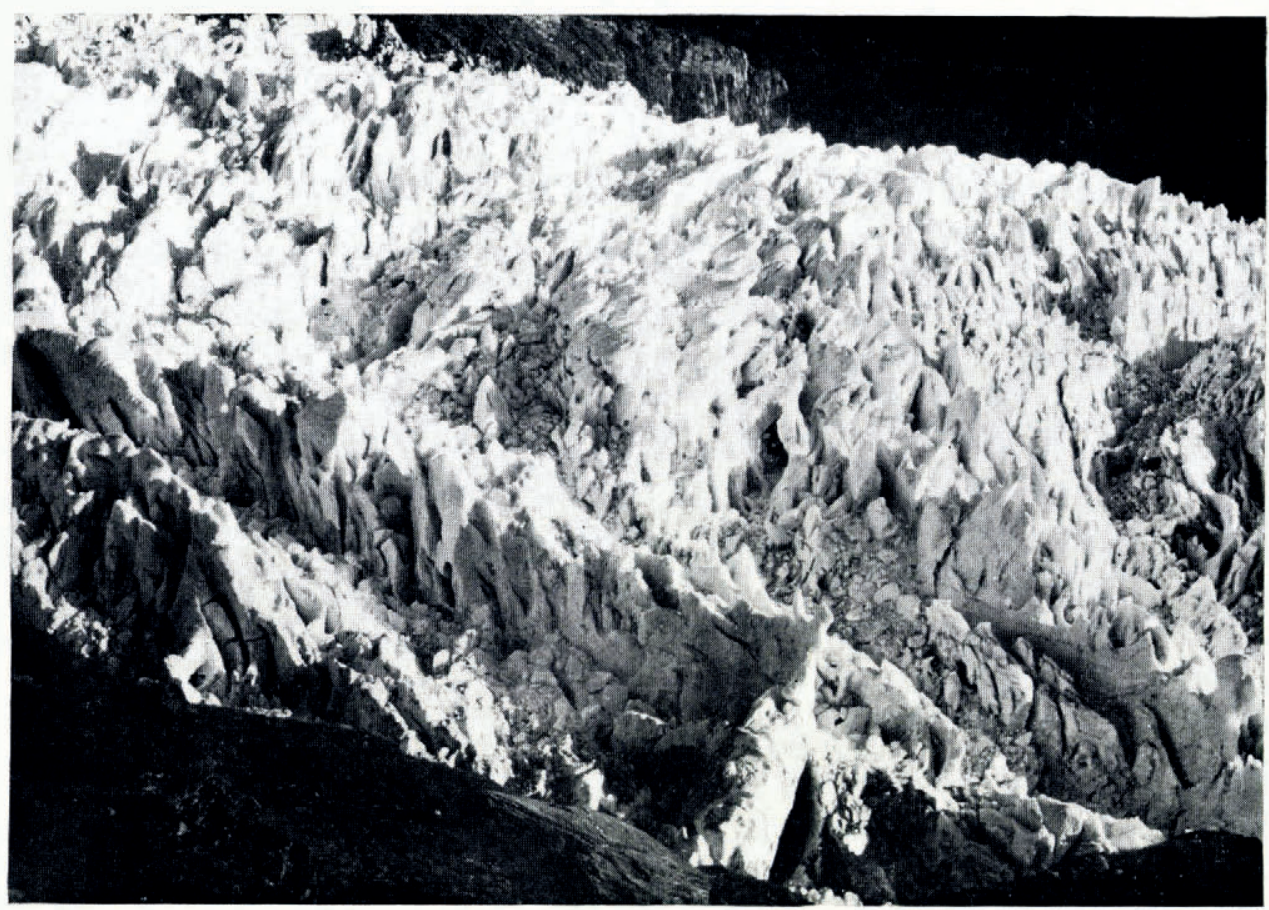

Fig. I6. The Fox Glacier ice fall viewed from Chancellor Hut. Note the U-shaped slumps which are concave down-stream

of a glacier under tension. In the course of passage down the ice fall these faults invert, first becoming straight and transverse to the line of the glacier flow and finally becoming a U-shaped series of ridges and hollows concave up-glacier at the foot of the ice fall (Fig. I 7) and resembling Forbes ogives in appearance. The compressive foliation which appears at the foot of the ice fall is parallel to them.

Possibly, as suggested by Nye (1952), the compressive foliation follows any suitably orientated plane of weakness already present.

\section{Crevasse Patterns}

The compressive foliation of Fox Glacier is, except in areas of local bottom irregularities, consistently associated with a pattern of concave chevron crevasses which crosses the foliation at right-angles (Fig. I8). This means that near the glacier margins the crevasses are nearly normal to the line of flow, while along the mid-line they usually consist of hair-line cracks nearly parallel to the line of flow.

In deforming ice the crevasse plane is normal to the maximum tension and parallel to the plane of maximum compression. This constant association between crevasse line and "veining", (foliation) was recognized long ago by Hopkins (I 862) but who nevertheless believed that the foliation was formed by pressure and not by shear as advocated by Forbes (1859). Hopkins failed to realize that, though the direction of maximum compression is normal to the foliation in plan, it diverges from it at a considerable angle in vertical section (Fig. I8).

Crevasses associated with the longitudinal foliation of Franz Josef Glacier are usually confined to within $100 \mathrm{~m}$. or so of the glacier margins except where the slope is convex, in 


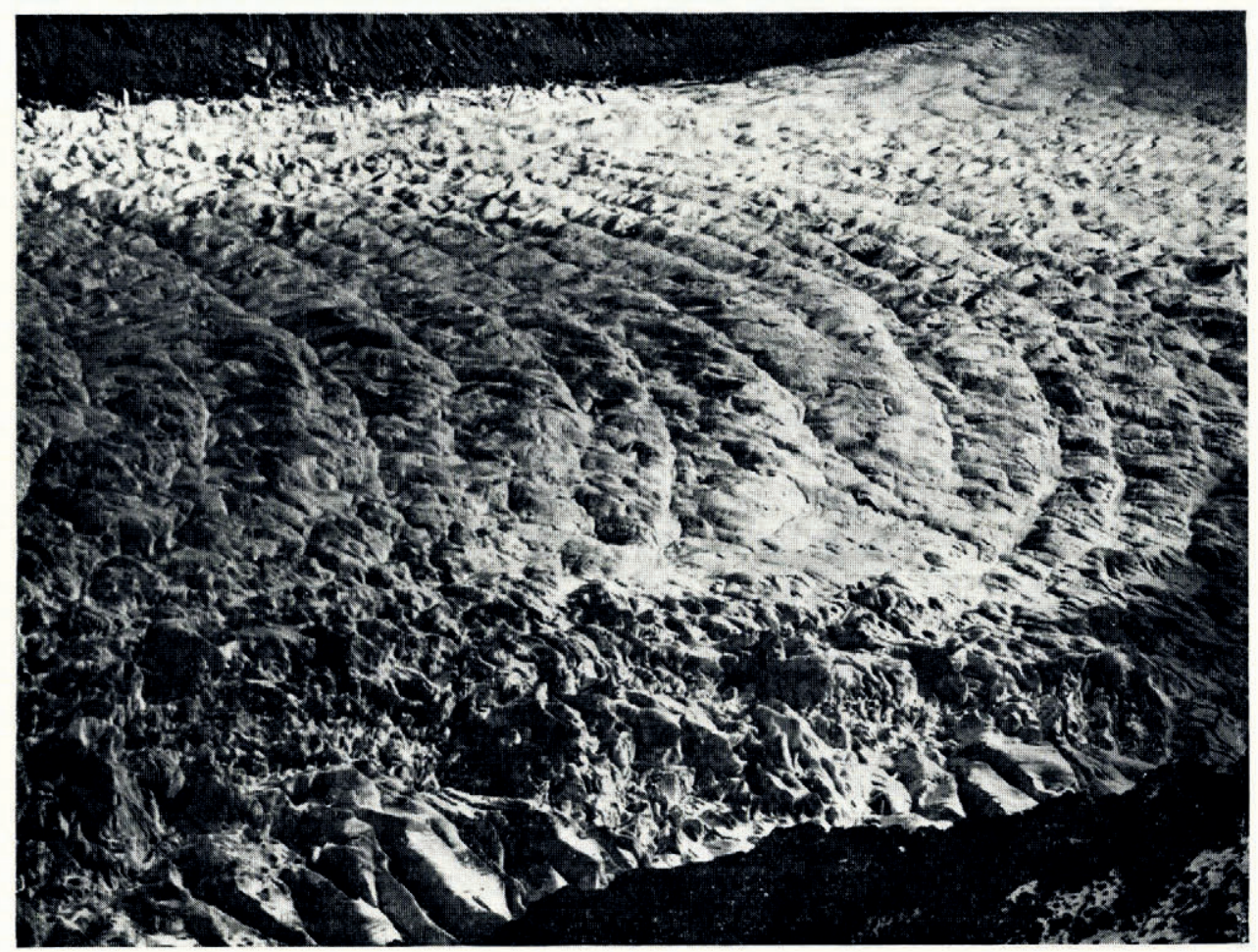

Fig. 17. The lower part of the Fox Glacier ice fall. Slumps have inverted, becoming concave up-stream on the right where they are parallel to a compressive foliation which can be faintly seen on the lower right (National Publicity Studios photograph)

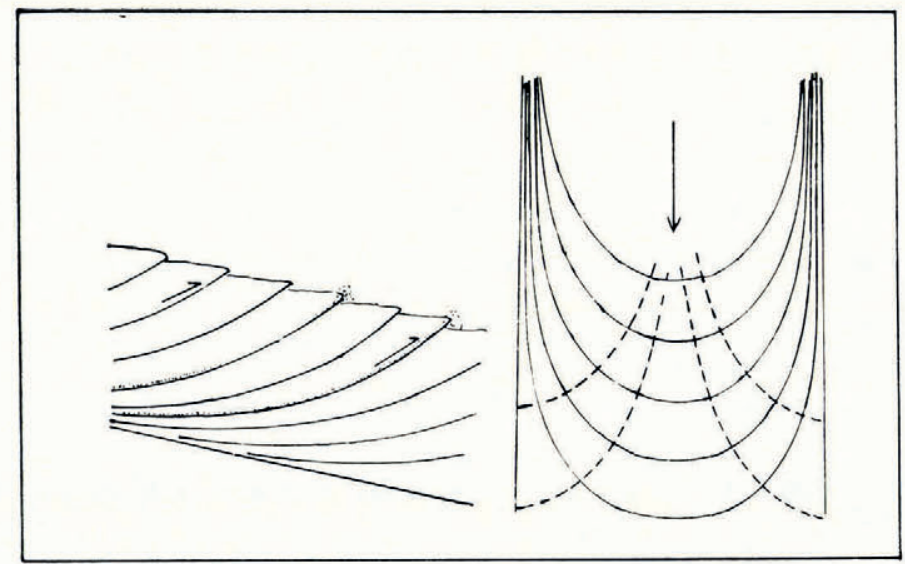

Fig. I8. Idealized vertical longitudinal and plan views of the lower Fox Glacier. Solid lines represent compressive foliation and moraine ogives; broken lines represent crevasses 
which case straight crevasses extend the full width of the glacier. Measurement of 60 crevasses showed that all of the marginal variety were formed at angles of $40-50^{\circ}$ to the valley sides. Differential flow causes the crevasses to rotate about vertical axes. After rotation of about $20^{\circ}$ they no longer continue to open and are melted out and vanish in a period of a few weeks.

\section{Ablation Rates}

Measurements of ablation rates on both glaciers were made by measuring the height of the ice surface from the bottom of a drilled hole $30-40 \mathrm{~cm}$. deep. The holes were invariably water filled and convection may have allowed some melting to take place at the bottom of the hole. Ablation rates vary greatly with weather conditions, being greatest on the frequent days of torrential warm rain.

At an altitude of $35^{\circ} \mathrm{m}$. on both glaciers the ablation at intervals spread over the months of January to April, averaged $8 \cdot 2 \mathrm{~cm}$./day without significant variation, the maximum being II $\cdot 2 \mathrm{~cm}$./day.

\section{Conclusions}

Under compression, glacier flow appears to take place by a combination of basal slip, differential slip along up-sloping planes with some plastic deformation, which can give rise to overturned folds in the old foliation which is then replaced by a new foliation closer to the theoretical slip planes. Whether slip is evenly distributed, confined to a few surfaces at a time, is regular or proceeds in a series of small jerks, as was found by Chamberlin (1928) in an overthrust in "Brenva Glacier", is not yet known.

The conditions under which the longitudinal foliation is formed are not well understood. Elongation of crystal fabric, flattening of air bubbles and the presence of cleavage suggest that here also the maximum compressive stress is inclined at an angle to the foliation and that shear is parallel to it. The flow-rate profiles (Fig. 13), however, show that there can be no differential movement between laminae in the horizontal longitudinal direction near the mid-line of the glacier, though the foliation is well developed there. Adjustment to change in width of the confining valley wall is made by crumpling and folding about vertical axes, as seen below Cape Defiance.

Flow in Franz Josef Glacier ranges between weakly compressive to weakly extensive. No foliation similar to the type deduced by Nye (1952) to be developed under conditions of extending flow has been observed. The slump faults concave down-glacier seen in the Fox Glacier ice fall may be a demonstration of extending flow, but ice may be too weak under tension to form a foliation and only a few slip surfaces are formed at intervals of roo $\mathrm{m}$. or more.

The longitudinal foliation is probably of laminar flow type but more refined techniques must be used to study why such a foliation should be found near the mid-line of a glacier and why it should be dipping steeply across a glacier many times wider than it is deep.

\section{Acknowledgements}

The writer wishes to thank the residents of the Waiho and Fox Glacier areas for information and help; also Mr. Ian McKellar of the New Zealand Geological Survey who rcad the script.

MS. received I6 August ${ }_{196} 6$ 


\section{REFERENCES}

Bell, J. M. 1910. A geographical report on the Franz Josef Glacier. Wellington, New Zealand Geological Survey.

Chamberlin, R. T. 1928. Instrumental work on the nature of glacier motion. Journal of Geology, Vol. 36, No. I, p. $\mathrm{I}-30$.

Forbes, J. D. I859. Occasional papers on the theory of glaciers. Edinburgh, Simpkin.

Gerrard, J. A. F., and others. 1952. Measurement of the velocity distribution along a vertical line through a glacier, by J. A. F. Gerrard, M. F. Perutz and A. Roch. Proceedings of the Royal Society, Ser. A, Vol. $213, N_{1}$ N $_{115}$, p. $546-58$.

Hopkins, W. 1862. On the theory of the motion of glaciers. Philosophical Transactions of the Royal Society, Vol. 152, Pt. 2, p. $677-745$.

McCall, J. G. I952. The internal structure of a cirque glacier: report on studies of the englacial movements and temperatures. Fournal of Glaciology, Vol. 2, No. 12, p. 122-30.

Meier, M. F., and others. I954. Preliminary data from Saskatchewan Glacier, Alberta, Canada, by M. F. Meier, G. P. Rigsby and R. P. Sharp. Arctic, Vol. 7, No. I, p. 3-26.

Nye, J. F. 1952. The mechanics of glacier flow. Journal of Glaciology, Vol. 2, No. 12, p. 82-93.

Perutz, M. F., and Seligman, G. 1939. A crystallographic investigation of glacier structure and the mechanism of glacier flow. Proceedings of the Royal Society, Ser. A, Vol. I 72, No. 950, p. 335-6o.

Reid, H. F. 1896. The mechanics of glaciers. I. Journal of Geology, Vol. 4, No. 8, p. 912-28.

Suggate, R. P. I950. Franz Josef and other glaciers of the Southern Alps, New Zealand. Fournal of Glaciology, Vol. I, No. 8, p. 422-29.

[Ward, W. H.] i953. Glacier bands: conference on terminology. Journal of Glaciology, Vol. 2, No. 13, p. $229-32$. 